\title{
A Comparative Study of the Malthusian Growth on Indian Economy by the Impact of Severe Acute Respiratory Syndrome and Corona Virus Disease 2019
}

\section{Soumitra Sahana ${ }^{1 *}$, Indranil Chatterjee ${ }^{2}$, Sabina Khatun ${ }^{3}$, Suman Kumar Nath ${ }^{2}$, Jafar Ansari ${ }^{1}$ and Indrajit Samanta ${ }^{1}$}

${ }^{1}$ B. Pharm, Birbhum Pharmacy School, Birbhum, West Bengal, India

${ }^{2}$ Assistant Professor, Birbhum Pharmacy School, Birbhum, West Bengal, India

${ }^{3}$ Lecturer, Birbhum Pharmacy School, Birbhum, West Bengal, India

*Corresponding Author: Soumitra Sahana, B. Pharm, Birbhum Pharmacy School, Birbhum, West Bengal, India.
Received: September 22, 2020

Published: November 18, 2020

(C) All rights are reserved by Soumitra

Sahana., et al.

\begin{abstract}
In December 2019, an outbreak of corona disorder reasons due to coronavirus-2, befell in Wuhan city, china. Later this virus is unfold and infect nearly all international locations in the world. As the no. of contaminated and demise instances will increase hastily World Health Organization (WHO) declare this as a pandemic. As it is a contagious disorder to keep away from spreading of contamination from individual to individual authorities declare extended lockdown in countries. Countries hostilities to deal with corona however in this way, financial system is badly stuck. The coronavirus outbreak is severely disrupting the international economy. Magnitude of financial influence is relying upon the length and severity of covid-19. In corona disaster humans no longer solely misery about fitness issue, however additionally due to monetary issue. The foremost contribution of this work is a comparative find out about of pre-Covid monetary situation and post-covid monetary condition. In this paper, we describe about covid-19 sickness and the viable methods in which spreading can controlled, and they have an effect on of lockdown on varies sectors. Major sectors are banking sector, tourism, agricultural region and pharmaceutical sector.
\end{abstract}

Keywords: Severe Acute Respiratory Syndrome; Corona Virus Disease 2019; Indian Economy

\section{Introduction}

In December 2019, adults in Wuhan, capital city of Hubei province and a main transportation hub of China began providing to native hospitals with extreme respiratory ailment i.e. pneumonia of unknown cause. Many of the preliminary instances had a usual publicity to the Huanan wholesale seafood market that additionally traded stay animals. China notified the irruption to the World Health Organization and on $1^{\text {st }}$ January the Huanan sea nutrients used to be closed. On seventh January the virus was once recognized as a coronavirus that had $>95 \%$ homology with the bat coronavirus and $>70 \%$ similarity with the SARS- Co V [1]. Phylogenetic evaluation suggests that although bats might also act as the unique reservoir for SARS- CoV-2, there is a opportunity of but any other unidentified intermediate host, which was once in all likelihood being offered at the seafood market in Wuhan earlier than the outbreak [2].
Coronaviruses (CoVs) are positively sensed single-stranded RNA viruses that belong to the order Nidovirales, household Coronaviridae, subfamily Orthocoronavirinae with four genera: alpha, beta, delta, and gamma coronaviruses [3]. This pathogen used to be later renamed as extreme acute respiratory syndrome coronavirus two (SARS- CoV-2) with the aid of the Coronavirus Study Group and the disorder was once named coronavirus sickness 2019 (COVID-19) through acute respiratory syndrome coronavirus two (SARS- CoV2) with the aid of the Coronavirus Study Group and the disorder was once named coronavirus sickness 2019 (COVID-19) through the WHO. As of January 30, 7736 tested and 12,167 suspected instances had been stated in China and eighty two demonstrated instances had been detected in 18 different countries [4]. Infection is transmitted by way of Droplets after coughing and sneezing, shut contact is the most frequent routes of transmission of SARS-CoV-2, and aerosol transmission can also be any other route. In addition, 
researchers have detected SARS-CoV-2 in samples of stool, gastrointestinal tract, saliva and urine. Based on bioinformatics, proof has indicated that the digestive tract may additionally be a route of SARS-CoV-2 infection [5]. As there is no medicine developed for novel corona virus sickness so there is a want for the deliberate graph of techniques for defending the contaminated surroundings which includes "social distancing methods" [3]. Maximum of the sufferers contaminated with the virus will journey frequent bloodless and flu, whilst few of them stay asymptomatic [6]. Avoid contact with ailing people, in specific these with a cough. Avoid traveling markets and locations the place stay or useless animals are handled, Wash your fingers with cleaning soap and water or use an alcohol primarily based disinfectant answer earlier than eating [7]. Pregnancy is a country of partial immune suppression which makes pregnant ladies extra inclined to viral infections Therefore, the COVID19 epidemic can also have serious penalties for pregnant women. Interim practice has been issued via the World Health Organization (WHO) and Centers for Disease Control and Prevention (CDC) on managing COVID-19, which consist of some tips unique to pregnant women. There seems to be some danger of untimely rupture of membranes, preterm delivery, fetal tachycardia and fetal misery when the contamination happens in the 0.33 trimester of pregnancy [8]. A file of 9 pregnant sufferers suggests that perinatal transmission is not going however large research are wanted to provide an explanation for this finding [9]. The ongoing outbreak of the corona virus disorder 2019 (COVID-19) contamination has posed significant threats to global health, and the economy [9]. On January 23, 2020, the Government of the Peoples Republic of China imposed a lockdown in Wuhan to quarantine, and stop the unfold of the disease [2] on March 24,2020, the authorities of India began lockdown this was once a drastic as nicely as forceful public fitness measure.

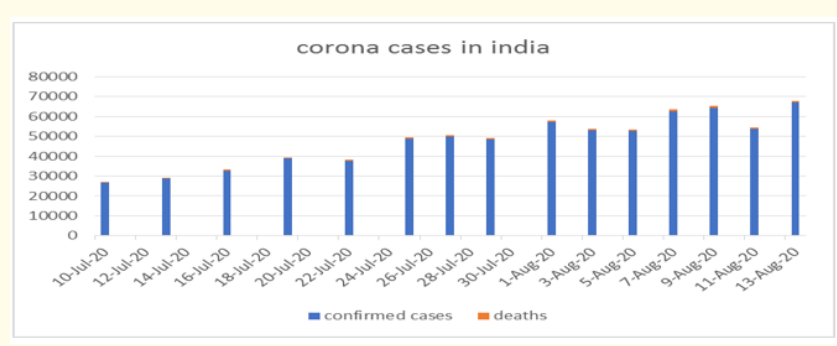

Figure 1: Comparative study of corona positive cases and death till 13 August 2020.

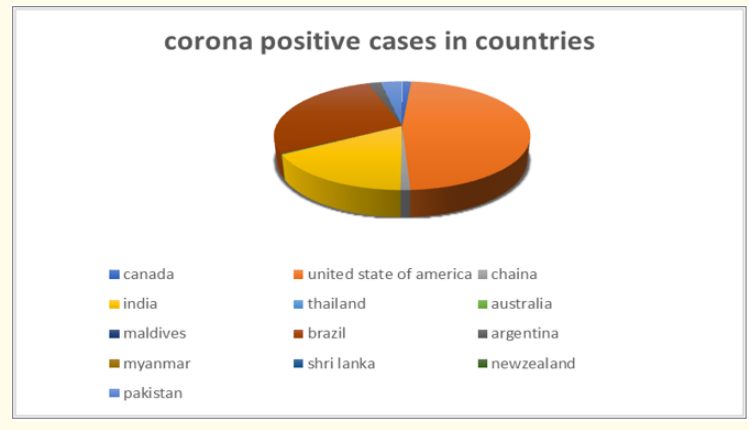

Figure 2: Corona cases in varies countries.

\section{Corona vs economy}

Corona crisis causes direct and indirect economic impacts across countries. The economic implications of the irruption is broadly termed as "Coronanomics" the irruption has produced a "de-globalization" process by forcing countries to lock-down borders, preventing normal flows of products, capital, and humans, and business and production shut- downs at least temporarily. That said, countries have already begun to feel the macroeconomic hit due to the irruption and economists are increasing looking into them [10].

As the pandemic unfold at some stage in the world, nations took drastic measures to shield their citizens. These measures targeted on reaching a fragile stability between limiting virus unfold from man or woman to man or woman and keeping financial activity. It was once an not possible balance, even though the timing of the implementation of these measures proved to be crucial, each for public fitness and SARS-CoV2 spread, as nicely as the monetary have an effect on every country [11]. Corona disease disturb countries via two major ways, health disturbance as well as economic disturbance. Situation in which the economic and social impact of coronavirus is emerging in low and middle-income countries. In order to stop a big amplify in poverty, we want to make complete use of present social safety structures and shortly raise money switch repayments to bad populace groups [12]. Indians banking zone has been going via a hard patch for the remaining 5 years. The wide variety of non-performing property (NPAs) has sky-rocketed. Public zone banks (PSBs) go through from an partner lack of ability to unravel heavy loans. This is partly as a end result of public area bankers have a very little incentive to get better loans [13]. In addition to this lockdown commenced in India. The COVID-19 
A Comparative Study of the Malthusian Growth on Indian Economy by the Impact of Severe Acute Respiratory Syndrome and Corona Virus

Disease 2019

pandemic has as soon as once more forcefully pushed societal inequalities into public consciousness. As countries, states, and cities started out the lockdowns. The COVID-19 disaster additionally underscored the vulnerabilities of corporations and societies to inequalities inside the fashion of public fitness Implications. As the sickness disrupted socioeconomic lives round the world, many giant companies had to shut down or restrict their operations. implications of the COVID-19 pandemic on enterprise is simply opening to emerge, The COVID-19 pandemic has severely disrupted financial activity, ensuing in tens of millions of humans dropping their jobs, or a giant phase of their monetary gain, at a very brief notice [14]. Loss of lives due to any pandemic motives exact irretrievable harm to society. But aside from this, COVID-19 has severely demobilized the international economy. According to World Trade Organization (WTO) and Organization for Economic Cooperation and Development (OECD) have indicated COVID-19 pandemic as the greatest risk to world economy [15]. Coronavirus sickness disturbs economic system of nearly all countries, as this virus is originated shape china, coronavirus outbreak is severely disrupting the Chinese economy. Large areas of the united states are below quarantine. It is affecting about 60 milions of people [16]. According to the survey, COVID-19 is having a 'deep impact' on Indian businesses, over the coming month's jobs are at an excessive hazard due to the fact companies are searching for some discount in the manpower [17].

\section{Corona vs shipping industry}

The consequences from the Coronavirus have begun to have a bad affect on a range of shipping-related industries and markets [18]. Coronavirus irruption is an herbal match has compacted the enterprise of cargo motion carrier providers. As per the sources, per day per vessel has declined by means of greater than $75-80 \%$ in dry bulk trade [17]. Since most of the global cargo ships halted in quarantine, there are probabilities that cargo backlogs will reason troubles to freight operators. In some cases, the containers are being dispatched returned to foundation due to the port congestion the place as some place gadgets are averting Chinese shipments [19].

\section{Corona vs pharmaceuticals industry}

Despite being one of the absolute best plans of medicine exporters on the earth, the drug employer enterprise of India relies upon neatly on import as of mass medications. Due to the coronavirus episode, it will possibly be affected [20]. Some chemical plant lives have been packed in China. Therefore, there will be restrictions on shipments. It simply was once located that $20 \%$ of the manufacturing has been impacted due to the disruption in uncooked fabric supply. China may want to be an essential dealer of Indigo that is required for denim. Business in India is probable going to result in affected consequently humans securing their supplies [21]. This troubles are badly impacted on pharmaceutical industry. India is one of the pinnacle system drug exporters in the world, the home pharma enterprise depends closely on import of bulk drugs, i.e. APIs and intermediate products. India imported round Rs 24,900 crore well worth of bulk pills in FY19 [22]. The coronavirus have an impact on has outburst in Indians pharmaceutical zone at a very large pace. It is affecting the pharma businesses with sure hikes inside the real price of key ingredients [23]. As per figure 3 comparison made between precovid and postcovid condition there are no any major changes occur on pharmaceutical sector, share prices of many pharmaceutical companies have been increases or it is remaining same. As Pharmaceutical sectors are active to fight with corona irruption so there is no any negative impact is observed.

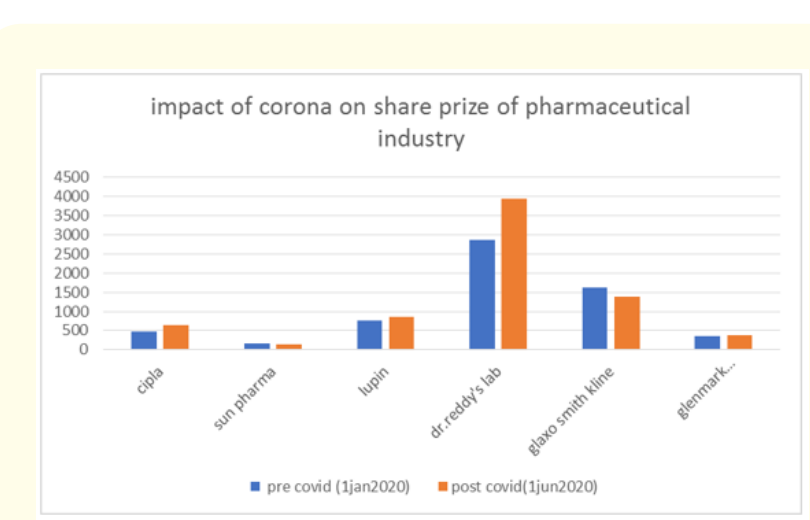

Figure 3: Comparative study of share prize of pharmaceutical industry.

\section{Corona vs agriculture industry}

The agriculture region is quintessential as giant range of employees, and consequently whole country's populace are structured on this sector. The overall performance of agriculture is moreover key to the nation of rural demand. 21-days lockdown and related disruptions will have an effect on agricultural activities, and consequently fundamental provide chains via many channels: enter distribution, harvesting, procurement, transport hurdles, advertising and processing. Restrictions of movement, and labour shortage may also hinder farming and meals process. March- April is that the season for the sale of the rabi manufacture however harvesting will get hampered due to the fact of the departure of 
A Comparative Study of the Malthusian Growth on Indian Economy by the Impact of Severe Acute Respiratory Syndrome and Corona Virus

Disease 2019

heaps of migrant workers [24]. In the longer term, the shipping of fertilizer with the aid of global markets may additionally turn out to be a trouble on the grounds that some manufacturing vegetation in China has been shut down [25]. The agriculture, and rural populace have to be included as social distance will be practiced comparatively much less in rural areas and it is going to produce a giant downside to natural phenomenon dealer as an end result of there is a hazard of Covid-19 spreading to the farmers, agricultural labourers, employees and others working for the duration of the meals furnish chains and it is due to the fact of $70 \%$ of the Indians populace who stay in rural areas. Some migrant employees have already long gone returned to rural areas [24]. The rooster enterprise alternate in various elements of the USA has been hit tough amid rumours that the novel coronavirus can transmitted thru consumption of chicken, the fee of which have fallen considerably as a result. About a two-crore human beings employed in the rooster enterprise throughout the US have been impacted. People had been averting consumption of meat, fish, chicken, and egg, etc. Due to the fall in demand, wholesale rate of rooster had dropped via as plenty as 70 percent [21]. Poultry farmers are badly hit due to the fact of misinformation especially on social media and some cities that chickens are the carriers of Covid-19 [24].

\section{Corona vs banking sectors}

During disaster times, one area of the economic system that is wanted to play a critical position concerning assuaging the pressures on the actual economic system is that the economic sector. The banking region in India is badly broken. So far, the problems in the course of the region have been adversely affecting credit score increase due to unpredictable shock of corona. One direct final result of the heightened hazard aversion inside a banking enterprise has been the scarcity of increase in industrial savings offer. Banks, specially the established Public area banks (PSBs) which account for shut to $90 \%$ of the non-performing property (NPAs), severely reduce lower back lending to the personal company sector. The penalties of heightened danger aversion inside the banking enterprise have begun hurting the debt markets. In a scenario the place financial institution deposit boom has been at a multi-decade low, debt market mainly the brief time period debt market performs a necessary position in financing firms [24]. During the pandemic, there was once an everyday decline in the quantity of financial institution transactions, a decline in card payments, and a fall in the use of ATM money machines worldwide. This led to fewer costs gathered by means of banks which negatively affected banks profit.
On the different hand, the lockdowns due to the coronavirus irruption resulted in greater demand for few kinds of online offerings such as on line shopping. The most seen effect of the COVID-19 disaster on economic markets used to be the impact in the world inventory market. In the identical period, massive worldwide banks witnessed a plunge in their share value, for example, ContiGroup's share rate fell by way of $49 \%$, JP Morgan Chases share cost fell by means of $38 \%$ [26].

Things might also show up a small quantity of nice for the monetary institutions. The banks region unit are predicted to decrease their work pressure drastically, decreasing the services and promotion on line services. E-banking is anticipated to improve like by no means before [27].

The mission for numerous banks is the way to operationalize these programs. Several core banking and mortgage accounting structures are simply now not set up for this kind of operational flexibility at scale. While the focal point of banks efforts must be short-term, this disaster may also very properly speed up many traits that have been already reshaping the banking industry. It's pretty feasible there will be no return to "business as usual." So, whilst temporary responses are in reality necessary, they may additionally lay a basis for longer time period commercial enterprise mannequin changes [28]. The plunge in global and home financial activity5 impacts all predominant sources of authorities earnings in the structure of tax. Estimates on tax buoyancy encouraged that tax revenues may want to contract a lot of powerfully than financial output. Lower organization profits, declining consumption and will increase in unemployment will, respectively, reason declines in income from company profits taxes, goods, and provider taxes, and private earnings taxes [11].

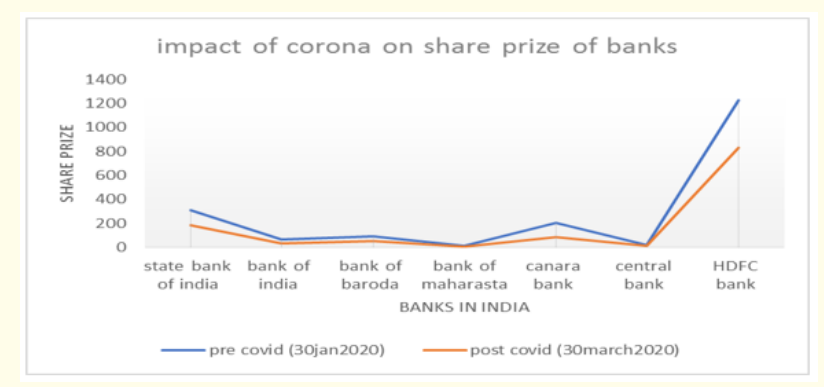

Figure 4: Comparisons of banking share prize before and after corona crisis. 
A Comparative Study of the Malthusian Growth on Indian Economy by the Impact of Severe Acute Respiratory Syndrome and Corona Virus Disease 2019

In the length of corona irruption earnings supply for most human beings were end due to the fact of lockdown, this mirrored on the banking transaction, it has been determined that the ratio of credited quantity is much less than the debited amount. This will create affect on banking sector. In figure 4 comparisons made between share prize of pinnacle banks in India, its suggests that the share fees of all referred to banks have been decreases in between the date 30 January 2020 to 30 march 2020. Negative have an impact on of corona used to be proven on share expenses of banking sector.

\section{Corona vs hospitals}

The COVID-19 pandemic has compact hospitals spherical the world. Various hospitals have scaled lower back or delayed nonemergency care [29]. Health middle agencies said a 43\% drop in the wide variety of affected person visits in contrast to earlier than the pandemic, as many of us throughout the use are heading off non-essential visits to fitness care providers [30]. In quite a few countries, the offerings of public hospitals grew in excessive demand alternatively the majority of the checking out instrumentation had been in personal hospitals. Health Insurers have been moreover affected. Insurance plan repayments to hospitals, and additionally the insurers sought to be enclosed inside the deliberate federal comfort stimulation bundle due to the fact the fitness sectors financial outlook used to be negative. Public interest healthcare sector's outlook from secure to terrible due to the fact of the endured unfold of the coronavirus disease. if the coronavirus outbreak may want to be contained, non-profit healthcare groups have been already dealing with rising fees and significant uncertainty [26]. High healthcare costs, shortages of shielding tools which include N95 face masks, and low numbers of ICU beds and ventilators have finally uncovered weaknesses in the shipping of affected person care [31].

The consequences of affected person declines and staffing troubles ought to have important implications for fitness facilities even after the pandemic. Leading up to the pandemic, the two most typically referred to challenges for fitness facilities had been monetary and body of workers issues, each of which have been exacerbated via the financial outcomes of the coronavirus [30].

Children's hospitals throughout the US of a are experiencing "catastrophic losses" after stepping up to assist in the COVID-19 fight [32].

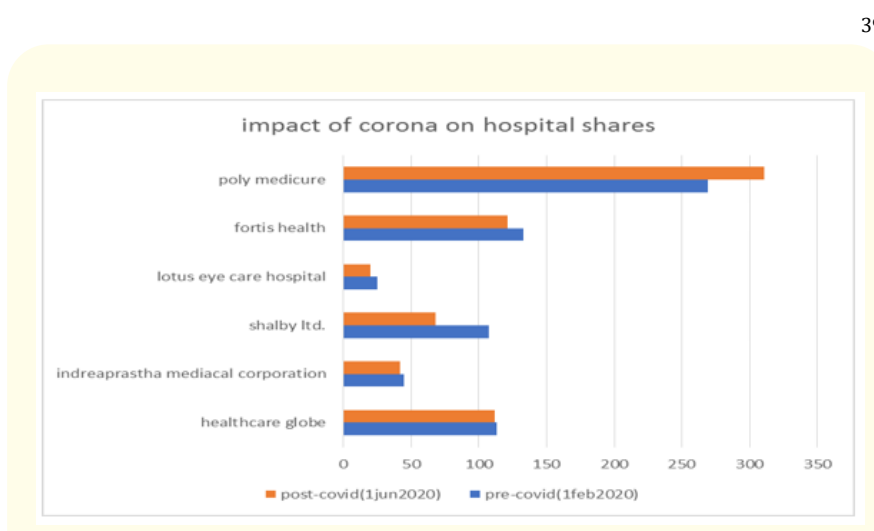

Figure 5: Comparative study of share prices of hospitals.

Hospitals are one of the most vital healthcare sectors, like a pharmaceutical sector, hospitals are additionally energetic in the corona irruption, attempting to decrease and managed corona condition. So, there is no any essential bad have an effect on is passed off on medical institution sector. In figure 5 evaluation is made between the share expenses of pinnacle most hospitals in India earlier than corona disaster and after corona crisis.

\section{Corona vs tourism sector}

The aviation zone has moreover been impacted by way of the unfold of coronavirus. The irruption has compelled home carriers to cancel and rapidly droop flights in operation from India to China and Hong Kong. Carriers such as Indigo and Air India has halted operations to China [22]. The Covid-19 pandemic has positioned the business organizations alternate below big economic strain. All industries location unit reeling then again it's the industrial company and hospitality region that has been hit the most given all the border closures, tour restrictions and lockdowns. Airlines, cruise operators and lodges region unit seeing immediately results of the pandemic [33]. While carrier oriented economies will take the large hits, international locations such as like Greece, Portugal, and Spain that are mostly reliant on tourism will be greater affected by means of this crisis [10]. The tourism area is presently one of the hardest-hit through the outbreak of COVID-19, with affects on every tour supplied and demand. The planet Travel and Tourism Council has warned that 50 million jobs inside the international journey and tourism area is additionally is in danger [31].

\section{Corona vs entertainment sector}

The international movie enterprise incurred a $\$ 5$ billion loss during the coronavirus irruption. Many Hollywood film produc- 
tions had been delayed indefinitely which supposed goodbye to theatre and cinema. The International Alliance of Theatrical Stage Employees (IATSE) stated that an estimated 120,000 below-theline leisure enterprise jobs have been misplaced due to the coronavirus pandemic, most of which had been theatrical stage employees [26].

Federation of Western Indian Cine Employees (FWICE) and Indian Film and Television Directors? Association (IFTDA) decide to halt capturing of film, TV indicates and internet series. Big releases postponed, film, TV and internet collection shootings halted, theatres unable to display movies, each day wage group of workers afflicted for their subsequent meal the Rs 183 billion Indian movie enterprise is going thru its worst segment due to the fact of the lockdown necessitated through the coronavirus pandemic. Covid-19 is preliminary have an impact on got here when Reliance Entertainment on March 12 indefinitely delayed Rohit Shetty's movie Sooryavanshi [34]. TV enterprise additionally badly affected due to this.

\section{Corona vs another sector}

\section{IT industry}

The New Year vacations in China has been prolonged due to coronavirus outbreak that adversely impacted the revenue, and boom of Indian IT companies [17].

\section{Hardware industry}

The big issue is China in devices being a remaining object or crude cloth utilized in the digital business. India's digital enterprise might also confront grant interruptions, creation, reduce sway on object fees due to the fact of overwhelming reliance on devices section grant legitimately or in a roundabout way, and close by assembling [20].

\section{Sport industry}

COVID-19 is having a tremendous have an impact on carrying schedules as some of the world's greatest wearing occasions come to view in 2020. Football's tons predicted Euro 2020 event has been postponed for 12 months whilst play-offs have been postponed till June 2020 at the earliest [31]. Indian Premier League (IPL), one of the most keenly awaited occasions in India has additionally felt the warmth of Coronavirus, with Board of Cricket Control of India (BCCI) figuring out to put off the begin of IPL season 2020 [35].

\section{Petroleum and oil}

In the course of a gathering at the Organization of the Petroleum Exporting Countries (OPEC) in countrywide capital on March $6^{\text {th }}$, a refusal through Russia to diminish oil manufacturing brought about Saudi Arabia to retaliate with brilliant reductions to buyers, and a chance to pump a lot of crude. Even though a deceleration in the variety of COVID-related deaths has prompted some stabilization of oil prices, there's nonetheless a great deal uncertainty [31].

\section{Real estate}

The actual property enterprise is dealing with exceptional uncertainty due to COVID-19. At an man or woman level, social distancing precautions have decreased residence views, a key phase of the promoting process, and each shoppers and retailers are having to rethink their plans. Increasingly, marketers are searching for reassurance related to the fitness of manageable consumers coming to view properties.

\section{Electronic industries}

Electronic Specifier's Lanna Cooper speaks to the enterprise to gauge feeling and outlook following the coronavirus pandemic, and its influence on electronics.

Cash transfer and food security by Pradhan mantri garib kalyan yojana

Government are do now not in a position to get their authorities profits in the structure of taxes, moreover authorities spend cash in a range of scheme for a wished man or woman as they can continue to exist in corona irruption. To limit the issues of the terrible all through the lockdown, the Central Government launched a "Prime Minister's Poor Welfare Package" of Rs 1.70 lakh crore. Special interest has been taken in this bundle to farmers, poor, women, employees, and workers. Due to Corona virus from the government's remedy package, there will be no hunger in the lock down and supply monetary aid to the wanted people.

In lockdown length Pradhan mantri garib kalyan yojana provides, $5 \mathrm{~kg}$ of rice/wheat per month free of price to the $800 \mathrm{mil}-$ lion bad humans in the country. Poor widows, aged and divyang get 1000rs per month, girls with jan dhan yojana bills get 500rs per month [37]. Underneath Kisan Samman Nidhi scheme farmers will be supplied ₹ 6000 at 12 months which would be frontloaded. Farmers will get the first instalment (₹2000/-) by using April 1, 2020 [38]. 


\section{Conclusion}

The contemporary covid-19 is an infectious disease, and it is badly affecting on more than a few sectors. By evaluating pre covid circumstance and put up covid situation on a number of sector, we come to recognize there is most important bad financial influence used to be created on a variety of sector. Health care sectors are barely affected, however the different sectors had been majorly impacted due to corona irruption. As lockdown have been commenced to manipulate corona condition, however it creates fantastic as properly as bad influence on society. As speak me about economic system of India a digital financial system is a main component coming below consideration, in corona irruption humans had been commenced adopting on-line price approach to hold social distancing. Demonetization push India into digital era, however the corona irruption forcing humans for adopting digital environment. But the unfold of corona virus is nevertheless spreading throughout the world and all the monetary sectors are impacted due to this. Our human fitness as properly as monetary fitness of a united states of America is in hazard for this, we have to take an advantageous selection to overcome from this situation.

\section{Bibliography}

1. Singhal T. "A Review of Coronavirus Disease-2019 (COVID-19)". The Indian Journal of Pediatrics 87 (2020): 281-286.

2. Aggarwal A., et al. "Clinical and immunological erythematosus patients characteristics in systemic lupus Maryam". Journal of Dental Education 76 (2012): 1532-1539.

3. Anjorin AA. "The coronavirus disease 2019 (COVID-19) pandemic: A review and an update on cases in Africa". Asian Pacific Journal of Tropical Medicine 13 (2020): 199-203.

4. Harapan H., et al. "Coronavirus disease 2019 (COVID-19): A literature review". Journal of Infection and Public Health 13 (2020): 667-673.

5. Wang L., et al. "Review of the 2019 novel coronavirus (SARSCoV-2) based on current evidence". The International Journal of Antimicrobial Agents 55 (2020): 105948.

6. Ahmad S. "A Review of COVID-19 (Coronavirus Disease-2019) Diagnosis, Treatments and Prevention". Eurasian Journal of Medicine and Oncology 4 (2020): 116-125.

7. Kumar D. "Corona Virus: A Review of COVID-19. Eurasian". Journal of Medical Oncology 4 (2020): 8-25.
8. Liang H and Acharya G. "Novel corona virus disease (COVID-19) in pregnancy: What clinical recommendations to follow?" Acta Obstetricia et Gynecologica Scandinavica 99 (2020): 439-442.

9. Hu Y., et al. "Prevalence and severity of corona virus disease 2019 (COVID- 19): A systematic review and meta-analysis". Journal of Clinical Virology 127 (2020): 104371.

10. Barua S. "Understanding Coronanomics: The economic implications of the coronavirus (COVID-19) pandemic (2020).

11. Gebhardt $\mathrm{H}$ and Siemers LH. "Impact of the Coronavirus Crisis on Public Finances”. Wirtschaftsdienst 100 (2020): 468-470.

12. Strupat C., et al. "Why social protection is crucial in the corona crisis (2020).

13. Forum EA. “Banking crisis impedes India's economy" (2019): 1-4.

14. Bapuji H and Allen DG. "Corona Crisis and Inequality: Why Management Research Needs a Societal Turn (2020).

15. Chakraborty I and Maity P. "Science of the Total Environment COVID-19 outbreak : Migration, effects on society, global environment and prevention". Science of the Total Environment 728 (2020): 138882.

16. Zandi M. "Coronavirus: The Global Economic Threat". Moody's Analytics (2020): 1-5.

17. What is the impact of Coronavirus on Indian Economy? (2020).

18. Effects on Shipping from the Coronavirus Effect Far and Wide Hellenic Shipping News Worldwide (2020).

19. Effects and Future of the Shipping Industry after Covid-19 Pandemic (2020).

20. Impact of corona virus on Indian Economy Inventiva (2020).

21. Suri G. "Impact of Demonetisation on Indian Economy". MERIJournal Management IT 12 (2018): 27.

22. Pharma Coronavirus and its impact on various sectors". The Economic Times (2020).

23. Impact of coronavirus on pharmaceutical sector (2020).

24. Mahendra Dev S and Sengupta R. "Covid-19: Impact on the Indian Economy". PAP Works (2020). 
25. Effects of Coronavirus on Agricultural Production - a First Approximation Agricultural and Rural Convention (2020).

26. Ozili PK and Arun T. "Spillover of COVID-19: Impact on the Global Economy”. SSRN Electron Journal (2020).

27. The effects of Corona on Banking Sector - Sesame India Blog (2020).

28. Acharya A. "Responding to Covid-19". Advances in Social Sciences Research Journal 7 (2020): 29-40.

29. COVID Surg C., et al. "Elective surgery cancellations due to the COVID-19 pandemic: global predictive modelling to inform surgical recovery plans". British Journal of Surgery (2020).

30. Impact of Corona virus on Community Health Center KFF (2020).

31. Nicola M., et al. "The socio-economic implications of the coronavirus pandemic (COVID-19): A review". International Journal of Surgery 78 (2020): 185-193.

32. Diaz A. "Coronavirus having "catastrophic" impact on children's hospitals: letter to HHS”. Fox News (2020).

33. Experts share insights on the effects of coronavirus on the tourism industry - Outlook Traveller (2020).

34. Covid-19 impact explained: How India's film industry got hit and is preparing for a new normal Explained News, The Indian Express (2020).

35. Coronavirus impact on IPL ecosystem value, Marketing and Advertising News, ET Brand Equity (2020).

36. Coronavirus impact on the electronics industry (2020).

37. Tanwar G. "Relief to the Indian Economy Struggling with the Corona Pandemic" 9 (2020): 2019-2021.

38. India announces Economic Support of 1.7 Lakh Crore in the wake of the Corona Crisis | Sarkari Yojanas (2020).

\section{Assets from publication with us}

- Prompt Acknowledgement after receiving the article

- Thorough Double blinded peer review

- Rapid Publication

- Issue of Publication Certificate

- High visibility of your Published work

Website: https://www.actascientific.com/

Submit Article: https://www.actascientific.com/submission.php

Email us: editor@actascientific.com

Contact us: +919182824667 